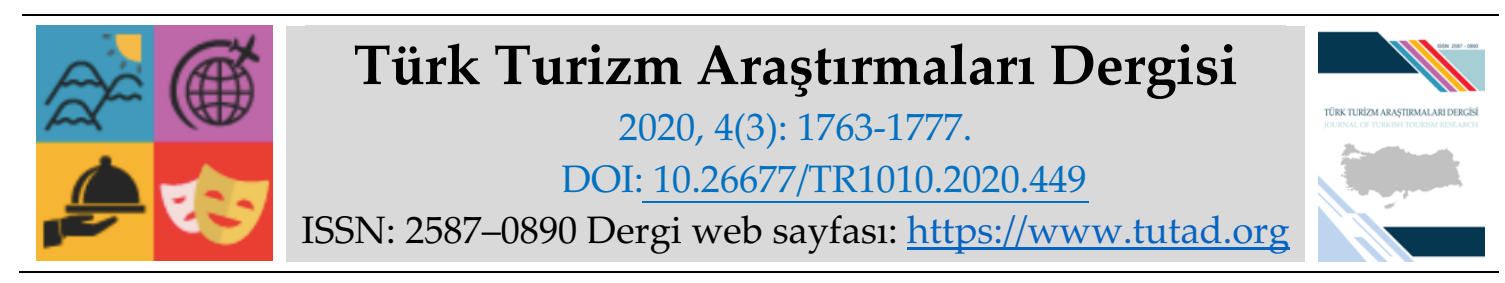

ARAȘTIRMA MAKALESI

\title{
Otel İşletmelerinde Çalışan Yöneticilerin "Stajyer" Kavramına İlişkin Algılarına Yönelik Metafor Analizi
}

Dr. Öğr. Üyesi Hande Mutlu ÖZTÜRK, Pamukkale Üniversitesi, Turizm Fakültesi, Denizli, eposta: hmozturk@pau.edu.tr

ORCID: https://orcid.org/0000-0002-4404-0106

Dr. Öğr. Üyesi Serap ALKAYA, Pamukkale Üniversitesi, Turizm Fakültesi, Denizli, e-posta: salkaya@pau.edu.tr

ORCID: https://orcid.org/0000-0002-0234-6692

$\ddot{O} z$

Yapılan bu araştırmanın amacı, otel işletmelerinde çalışan yöneticilerin "stajyer" kavramına ilişkin sahip oldukları metaforları belirlemektir. Araştırmaya, 29'u erkek 16'sı kadın olmak üzere toplam 45 yönetici katılmıştır. Araştırma verileri, metafor formu ile toplanmıştır. Formda katılımcılardan "Stajyer ...... benzer, çünkü ........" ibaresini tamamlamaları istenmiştir. Elde edilen veriler nitel araştırma yöntemleriyle analiz edilmiştir. Katılımcılar stajyer kavramına ilişkin 30 adet metafor üretmiştir. Katılımcılar tarafından belirlenen metaforların ortak özelliklerine bakılmış, birbirleri ile ilgili olanlar aynı kategori altına alınmıştır. Bu işlem sonunda 30 metafor, ilgilenildikçe gelişen birey, yokluğu eksiklik, varlığ yenilik yaratan birey, tecrübeyle gelişecek birey ve geleceğe yön verecek birey olmak üzere toplam 5 kategori altında toplanmıştır.

Anahtar Kelimeler: Stajyer, Metafor, Alg1, Otel İşletmeleri.

Makale Gönderme Tarihi: 03.04.2020

Makale Kabul Tarihi: 07.07.2020

\footnotetext{
Önerilen Atıf:

Öztürk, H. M. ve Alkaya, S. (2020). Otel İşletmelerinde Çalışan Yöneticilerin "Stajyer" Kavramına İlişkin Algılarına Yönelik Metafor Analizi, Türk Turizm Araştırmaları Dergisi, 4(3): 1763-1777.

(c) 2020 Türk Turizm Araştırmaları Dergisi.
} 


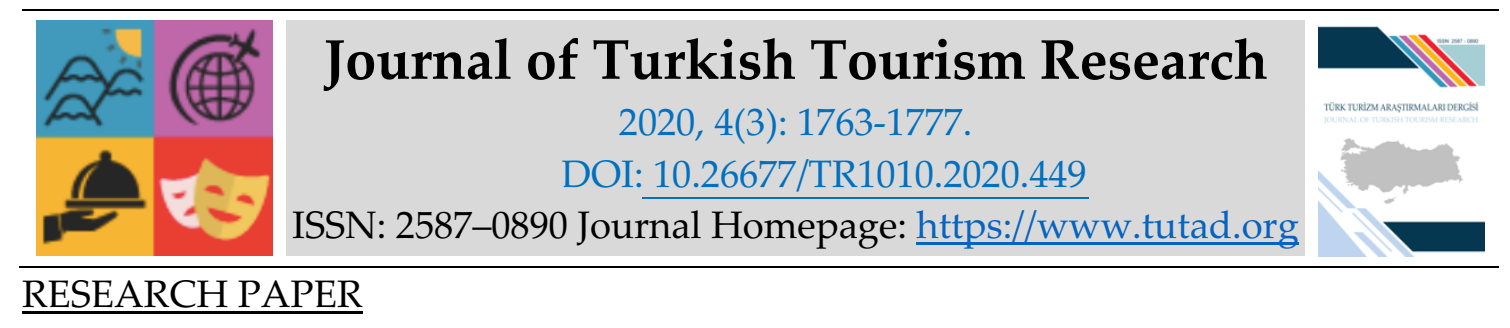

\title{
Metaphor Analysis of the Perceptions of Managers Working in Hotel Businesses Regarding the Concept of Intern
}

Assistant Prof. Dr. Hande Mutlu ÖZTÜRK, Pamukkale University, Tourism Faculty, Denizli, email: hmozturk@pau.edu.tr ORCID: https://orcid.org/0000-0002-4404-0106

Assistant Prof. Dr. Serap ALKAYA, Pamukkale University, Tourism Faculty, Denizli, e-mail: salkaya@pau.edu.tr ORCID: https://orcid.org/0000-0002-0234-6692

\begin{abstract}
The purpose of this research is to determine the metaphors of the managers working in hotel businesses regarding the concept of "intern". A total of 45 managers, 29 men and 16 women, participated in the study. The research data were collected with the metaphor form. In the form, participants were asked to complete the phrase "Intern resembles ........., because .........". The data obtained were analyzed by qualitative research methods. The participants produced 30 metaphors about the concept of the trainee. The common features of the metaphors determined by the participants were examined, and those related to each other were placed under the same category. At the end of this process, 30 metaphors were gathered under a total of 5 categories: an individual who develops with interest, an individual whose absence is deficient, whose existence is innovative, an individual who will develop with experience and an individual who will shape the future.
\end{abstract}

Keywords: Intern, Metaphor, Perception, Hotel Businesses.

Received: 03.04.2020

Accepted: 07.07.2020

\section{Suggested Citation:}

Öztürk, H. M. and Alkaya, S. (2020). Metaphor Analysis of the Perceptions of Managers Working in Hotel Businesses Regarding the Concept of Intern, Journal of Turkish Tourism Research, 4(3): 1763-1777.

(C) 2020 Türk Turizm Araştırmaları Dergisi. 


\section{Gíriş}

Hizmet sektörü tüm dünyada en hizlı gelişen alanlardan bir tanesidir. Türkiye'de de hizmet sektörü hızlı gelişme gösterdiğinden ülke ekonomisindeki yeri gün geçtikçe artmaktadır. Otel işletmeleri bu bağlamda ülke ekonomisine katkısı da göz önünde bulundurularak hizmet sektörü içinde önemli bir rol oynamaktadır. Bu işletmelerin verimliliği doğrudan hizmet kalitesiyle ilişkilidir. Pender ve Sharpley (2004), otel işletmeciliği ile ilgili üç önemli ve birbiriyle ilişkili otel işletmesi alanı olduğunu öne sürmektedir. Bunlar, her biri kilit yönetim "sonuç alanları" olarak tanımlanabilecek müşteriler, işgücü ve işletmenin varlıklarıdır. Turizm işletmelerinde işgücünü oluşturan personelin mesleki eğitimi ve tecrübesi işletmeye gelen ziyaretçilerin memnuniyetini ve hizmet kalitesini etkilemektedir, bu nedenle yetişmekte olan işgücüne verilen değer önemli bir unsurdur. Eğitim kurumları nitelikli işgücü yetiştirmek ve öğrencilerin sektörü tanımalarına fırsat vermek için staj uygulaması yapmaktadırlar. Yapılan staj uygulamasının amaca ulaşabilmesi için işletmelerin stajyer öğrencilere yaklaşımı son derece önemlidir. Bu çalışma ile yöneticilerin stajyerlik kavramına ilişkin bakış açıları değerlendirilecektir.

\section{KAVRAMSAL ÇERÇEVE}

Metafor kelimesi Yunan kökenli bir kelimedir ve "meta: öte" ve "pherin: taşımak" kelimelerinin bir araya gelmesiyle oluşturulmuştur. Anlam olarak ise "bir şeyi başka bir şey ile anlatmak" için kullanılmaktadır (Parın, 2017). Dann (2002) metaforun en temel özelliğinin kültürel kodlar içermesi olduğunu, kültürden kültüre değiştiğini ve bu nedenle de metaforların evrensel olamayacağından söz etmiştir. Nöth'e (1990) göre metafor dar veya geniş anlamda düşünülebilir. Birincisi, özel bir alanı kapsarken, ikincisi kelime dağarcığının alışılmadık tüm kullanımlarına, geleneksel dilden tüm ayrılmalara uygulanabilir. Kelimenin ilk anlamını alan metafor, transfer (değiştirme, değiştirme, çeviri) ve benzerlik (benzerlik, karşılaştırma, analoji) özelliklerine sahiptir. Bu nedenle metafor genellikle 'keyfi' olduğu söylenen değişmezin aksine (geleneksel olarak) kabul edilir.

Metafor iki 'farklı şeyi paylaştıkları özelliklere göre karşılaştırdığından, 'x y'dir' şeklini alır (örneğin, 'zaman nakittir' ifadesi) (Elgin, 1993). Burada, dikkatle seçilmiş ve iletilmiş benzerlik noktaları üzerinde odaklanılmıştır. Hem konuşmacı hem de dinleyicinin karşılaştırmayı anlaması şartıyla, metafor "insanların tutumlarını hızlı, etkili ve kalıcı bir şekilde değiştirmek için kullanabilecek en güçlü cihaz" olabilir (Elgin, 1993). Öte yandan, metafor paradoksal olarak, dilsel yoksulluk belirtileri gösterebilir, çünkü aynı kelimenin farklı durumlarda kullanılması kelimelerin seçiminde bir sınırlama ortaya koyabilir. (Burke, 1966). Bu nedenle dilin zenginliği metaforları daha çok zenginleştirir. Metafor kullanımı anlatımı zenginleştirir. Metaforlar insanların hayatlarını nasıl sürdüreceğini büyük ölçüde etkilemektedir. Metaforlar kullanıma göre insanlar için gerçeklikler yaratabilmektedir. Bu durum özellikle sosyal hayatlara yansımaktadır. Bu nedenle eylemler üzerinde kılavuz gibi bir etkisi olabilmektedir, yani günlük hayatta kullanılan metaforlar kişilerin davranış biçimlerine dönüşebilmektedir (Parın, 2017).

Adu-Ampong (2016)'a göre bir asır öncesine kadar bir mecaz sadece bir konuşma figürüyken, söylem analizinin gelişmesiyle, metaforlar daha fazlasını temsil etmeye başlamıştır. Birçok durumda metaforlar, dünyaya bakmak, görmek, anlamak ve gerçekten yeniden yapılanmanın bir yolunu temsil ederler. En temel anlamda metafor, bir kavramın diğer bir kavramla temsil edilerek kullanılmasıdır. Hızla değişen sosyal dünyada metaforlar, mevcut kelime dağarcığ yetersiz olduğunda devam eden dönüşümleri anlamanın yeni yollarını sunar. Turizm ve "tropikal cennet", "kutsal bir yolculuk olarak turizm" ve "çocuk olarak turizm" ile ilişkili geleneksel metaforlar vardır. Metaforlar günlük dilde yaygındır ve bu nedenle bilgi 
dağarcığımızda önemli bir rol oynar. İnsan düşünce süreçleri - yani bizim kavramsal sistemimiz - mecazi olarak yapılandırılmış kabul edilir (Lakoff ve Johnson, 1980). Böylece bilinçli ya da bilinçsiz olarak 'yaşadığımız' metaforları seçtiğimizde gerçekliğimizi aynı anda şekillendiririz. Sosyal bilimlerde dilbilimsel dönüşün ardından, dil ve metafor analizleri siyaset bilimi, sosyoloji ve politika çalışmalarında, dilbilim ve beşeri bilimlerde geleneksel dayanaklarını bırakarak önem kazanmaktadır (Carver ve Pikalo, 2008; Cameron ve Maslen, 2010).

Günay ve Düşmezkalender (2019) çalışmalarında "metafor" kavramını incelemişler, "metafor" un çeşitli tanımlarını gözden geçirmiş ve kavramların mecazi anlamlarını tartışmışlardır. Metaforlar, kavramları, olguları veya nesneleri tanımlarken kullanılan alternatif yaklaşımlardır. Farklı ifadelerle bireylerin hayali ve hayali düşüncelerini temsil ederler. Bu şekilde, tanımlanmış bir kavram, aynı anlama gelmekle birlikte, farklı sözcükler ve farklı yönlerden açıklanabilir. Metaforlar, özellikle belirli bir kavrama yönelik algıları ortaya koymaları bakımından önemli kabul edilirler.

Turizm alanında metafor kavramı özellikle son yıllarda farklı konular için çalışılmıştır. Ehtiyar, Solmaz ve Çağla (2019) yaptıkları çalışmada turizm alanında çalışan akademisyen kadınların simgesel olarak nasıl algılandıklarını görebilmek için metafor yaklaşımını kullanmışlardır. Farklı üniversitelerde turizm eğitiminde görev alan kadın akademisyenlerin neye benzetildikleri ve neden bu benzetmenin yapıldığını görmek için yürütülen çalışmada metafor temaları olarak "mücadele etmesi gereken", "çoklu görevlere sahip" ve "çalışkan biri olarak kadın akademisyen" temaları olduğu ifade edilmiştir. Aynı çalışmada "zarif", "engellenen", "üretken", "mucizevi bir varlık", "enerjik", "güçlü", "fedakâr", "yol gösterici", "uyum sağlaması gereken" ve "denge sağlaması gereken biri" kavramlar öne çıkmıştır.

Güllü, Kendir ve İnce (2016) yaptıkları çalışmada turizm eğitimi alan lisans öğrencilerinin iş değeri algıları ve mesleğe devam niyetleri üzerine incelemede bulunmuşlardır. Elde ettikleri bulgulara göre öğrencilerin mesleğe devam konusunda kararlı olmadıkları sonucuna ulaşmışlardır. Bir diğer çalışmada, turizm alanında önlisans eğitimi alan öğrencilerin, staj öncesi ve sonrası görüşleri değerlendirilmiş ve elde edilen bulgular öğrencilerin staja ilişkin görüşlerinin staj tamamlandıktan sonra olumsuzlaştığı yönünde bulunmuştur (Emir, Pelit ve Aslan, 2010).

Özder, Kaya ve Ünlü (2012) çalışmalarında ortaöğretim öğrencilerinin turizm kavramına yönelik algılarını belirlemeye ve bu amaçla turizm kavramı ile örtüşen metaforları ortaya çıkarmaya çalışmışlardır. Turizm kavramına ilişkin ortaöğretim öğrencilerinin Lokanta, müzik, türkü, İngilizce, yabancı dil, güneş, dolar, turist otobüsü, fotoğraf makinası, kamera, yemek, dil pratiği, han, hamam, harita, miras, döviz gibi metaforları kullandıkları görülmüştür. Benzer bir tematik çalışma Taş, Düz ve Ünlü (2016) tarafından yürütülmüştür ve bu çalışmada orta öğretimde eğitim alan öğrencilerin turizm algısını belirlemek için metafor yaklaşımını kullanmışlar ve "alternatif turizm" kavramına ilişkin algının belirlenmesine çalışmışlardır. Bu amaçla özel ve devlet okullarında okuyan ortaöğretim öğrencilerine uygulanan anket çalışmasında olgu bilim deseni kullanılmıştır. Bulgularda olağan şeyin dışında, değişik turizm, çok çeşitli, sıra dışı, ekstra turizm gibi metaforların öne çıktığı görülmüştür.

Turizm alanında öğrenim gören öğrencilerin 'Rekreasyon' kavramına yaklaşımlarını metafor yöntemi kullanarak görmek amacı ile yürütülen çalışmada Gözen (2019) analizinde içerik analizi yöntemi ve kelime sorgusu yöntemini kullanmıştır. Yapılan çalışmada en çok tekrar eden kelimelerin belirlenmesi için frekans analizi yöntemi ve temaların oluşumunda kullanılan kelimelerin belirlenmesi için ise kelime diyagramları kullanılmıştır. Bu tür çalışmalarda önemli kavramlardan birisi olan metaforun "konu ve kaynak" arasındaki ilişkinin belirlenmesinde 
"gibi" kelimesi kullanılmış; metaforlara arka planda ne anlam yüklendiğinin görülmesi için ise "çünkü" ifadesi seçilmiştir.

Gözen (2019) bir olgunun metafor olarak kabul edilebilmesi için;

1. Metaforun konusu nedir?

2. Metaforun kaynağı nedir?

3. Metaforun kaynağından konusuna atfedilmesi düşünülen özellikler nelerdir? gibi sorulara cevap verilmesi gerektiğini ifade etmiştir.

Meslek lisesi ve turizm yüksek okulunda öğrenim gören öğrencilerin termal turizme ilişkin algılarının metafor yöntemi kullanarak belirlenmesi için yürütülen çalışmada Bilgen ve diğerleri (2014) olgu bilim deseni (fenomenoloji) kullanmış ve içerik analizi tekniğini kullanarak verilerin analizini gerçekleştirmişlerdir. Yapılan çalışmada 180 öğrenciye anket uygulanmış ve öğrencilerin 46 metafor ürettikleri ve bunların 4 kategoride toplanabileceği çalışmada belirtilmiştir. Benzer konuda bir diğer çalışma Canbaba ve Canbaba (2020)'de yapılmış ve 83 öğrenciye yarı yapılandırılmış anket uygulanmıştır. Çalışmada öğrencilerin termal turizme yönelik 31 metafor ürettikleri ve bunun da 5 farklı kavramsal kategori altında ele alınabileceği belirtilmiştir. Termal turizm konusunda öğrencilerin en fazla 16 frekansla tekrar edilen \%21,62 ile 'Kaplıca' metaforu olurken onu 10 frekans ve \%13,51 ile Pamukkale metaforu izlerken 3. Sirada 9 frekans ve \%12,6 ile sağlık izlemiştir. "Türk Mutfağı" konusunda Turizm Rehberliği alanında öğrenim gören öğrencilerin algılarının ortaya konulabilmesi için yürütülen bir çalışma ile 281 öğrenci ile anket yöntemi kullanılarak yürütülen çalışmada, Köroğlu, Manav ve Karaca (2018) metafor yaklaşımını kullanmışlardır. Yapılan çalışmada öğrencilerin 154 metafor ürettikleri ve 10 kategori altında toplanabileceği çalışmada gösterilmiştir. Çalışmada "doğa ile ilgili metaforlar", "kültür-sanat ile ilgili metaforlar", "verilen önem ile ilgili metaforlar", "yiyecek-içecekler ile ilgili metaforlar", "soyut kavramlar ile ilgili metaforlar", "mekân ile ilgili metaforlar", "canlı varlıklar ile ilgili metaforlar", "nesneler ile ilgili metaforlar", "klasik bir alg1 olarak mutfak ile ilgili metaforlar" ve "diğer metaforlar"ın kullanıldığı belirtilmiştir.

Turizm ve kültür konusundaki algılanmanın belirlenmesi amacı ile yürütülen çalışmada, Anadolu lisesi ve mesleki ve teknik liselerde öğrenim gören öğrencilere anket yöntemi kullanarak metafor yaklaşımı uygulanmıştır (Gürsoy ve Sonuç, 2020). Çalışmaya toplam 261 öğrenci katılmıştır. Çalışmada, "Turizm", "Kültür" ve "Turizm ve Kültür" konularındaki üretilen metaforlar belirlenmiştir. Çalışmada turizm eğitimi alan lise ve üniversite öğrencilerinin turizm, kültür ve bu iki terimin ilişkisine dair farkındalık düzeylerinin yüksek olduğu gözlemlenmiştir. Turizm ve otel işletmeciliği bölümü önlisans öğrencilerinin "turizm" olgusuna ilişkin metaforik algılarının belirlenmesi amacı ile yürütülen diğer bir çalışmada ise Saçılık, Çevik ve Özkan (2016) öğrenciler "Turizm" konusunda 97 farklı metafor üretmişlerdir. Yapılan çalışmada öğrencileri ürettikleri metaforların en çok eğlence (36), para (22), deniz-kum - güneş (10), dinlenme (10), sosyalleşme (9), tatil (9) ve özgürlük (9) olarak kategorilere ayrılabileceği belirtilmiştir. Yapılan çalışmada önlisans öğrencilerinin \%31,6'sı klasik algıya; \%16,73'ü psikolojik algıya; \%15,24'ü finansal algıya; \%11,15'i gelişim aracı algısına; \%6,69'u sosyolojik algıya; $\% 6,32$ 'si canlı ve somut varlık algısına; \%5,21'i tarihi ve kültürel algıya; \%4,09'u eylem algısına ve \%2,97'si ise edebi değer algısına sahip oldukları görülmüştür.

Turizm sektöründe çalışan orta ve alt düzey otel çalışanlarının "turizm", "barış" ve "turizmbarış" bakış açılarının görülmesi amacı ile yürütülen bir çalışmada metafor olgusu kullanılmıştır. Kulakoğlu Dilek, Dilek ve Gümüş (2016) tarafından yürütülen çalışmada metaforik algılar ekonomik, duygusal, ilişkisel ve holistik (bütünsel) algı gibi 4 temel kategoride toplanmıştır. 
Yapılan çalışmada turizm çalışanlarının turizm ve barışı birbirini tamamlayıcı unsurlar olarak gördüklerini göstermiştir.

Seyitoğlu ve Çakar (2017) metaforik yaklaşım ile ilgili bir çalışma yaparak çalışmada turizm lisans öğrencilerinin eğitim ve staj deneyimleri ile ilgili metaforik analiz algılarını incelemişler ve turizm eğitimcilerinin metafor kullanmaya yönelik farkındalıklarını araştırmışlardır. Çalışmada metafor yaklaşımını araştırmak için nitel bir metodoloji kullanılmıştır. Katılımcılar, Antalya Akdeniz Üniversitesi Turizm Fakültesi'nin öğrencilerinden seçilmiş ve çalışmaya 94 öğrenci katılmıştır. Veriler yarı yapılandırılmış bir anketle toplanmış ve içerik analizi kullanılarak işlenmiştir. Daha sonra, cevaplarda bulunan metaforlar farklı gruplara ayrılmış ve ilgili metinler belirlenmiştir. Sonuçlar hem turizm eğitimi sağlayıcıları hem de turizm işletmeleri için yararlı bilgiler içermektedir. Bu çalışmada katılımcı lisans öğrencilerinin eğitim programlarına ve stajlarına ilişkin algıları ve kavrayışları ortaya konulmaya çalışmıştır. Çalışmada turizm eğitimcilerinin öğrencilerinin öğretme ve öğrenme sürecine ilişkin algılarını kavramak için yüksek öğretimde metafor kullanma bilincini artırmak, amaçlanmıştır. Çalışmanın sonuçları katılımcıların hem turizm eğitim kurumları hem de kuruluşları için önemli etkileri olan olumlu, olumsuz ve tarafsız bakış açılarına sahip olduğunu ortaya koymuştur. Çalışma ile eğiticilerin öğrencilerin ihtiyaç ve beklentilerini incelemek ve anlamak için metafordan yararlanabileceğini gösterirken, bulgular ideal turizm eğitiminin ve daha iyi staj koşullarının entegrasyonunun öğrencilerin gelecekteki kariyerleri için fırsatlar sağlayabileceğini göstermiştir. Bu çalışmada veri analizinin ilk aşamasında, katılımcıların turizm eğitimi ile ilgili fikir ve düşüncelerinde yer alan yedi konu ve veri analizinin ikinci aşamasından sonra ise altı ana tema, stajyerle ilgili metaforlara atıfta bulunmaktadır.

Seyitoğlu ve Çakar (2017)'ın çalışmasının en çarpıcı yanı stajlara ilişkin olarak gerçekleştirdikleri ikinci metafor grubu olmuştur. Çalışmada sektörde stajyerlerin nasıl görüldüğü ile ilgili, stajyerlerin bakış açısı görülmeye çalışılmıştır. Çalışmada, stajyerlerin gözü ile bakıldığında sektörde stajyerlerin tam olarak dikkate alınmadığı, önemli görülmedikleri not edilmiştir. Stajyerlerin motive edilmeleri ve eğitilmeleri gerektiği belirtilerek, stajyerlerin bakış açılarına göre kendilerinin ucuz emek olarak görüldükleri şeklinde özetlenebileceği belirtilmiştir. Ayrıca, stajyerlerin sektörde kalmak için yeterince cesaretlendirilmedikleri, bu durumun onları hayal kırıklığına uğrattı çünkü beklentilerinin turizm kuruluşları tarafından karşılanmadığı stajyerler tarafından ifade edilmiştir. Daha önce yapılan birçok çalışmada stajların öğrencilerin sektörü ve çalışma ortamını tanımaları için çok önemli olduğu gösterilmiştir (Zopiatis ve Constanti, 2007). Stajyerler staj esnasında bilgi ve becerilerini geliştirebilmektedir (Chen ve Gürsoy, 2008; Cook, Parker ve Pettijohn, 2004) ve bu da onların kişisel gelişimleri için oldukça önemlidir.

Atieno ve Njoroge (2018) çalışmalarında ekoturizm kavramının Kenya'daki turizm paydaşları arasında çevresel davranışlar için bir metafor olarak ele almıştır. Çalışmada, turizmdeki "eko" ön eki metaforu, paydaşlara diğer ilgi alanlarına hizmet eden ekonomik ve sosyal mantıklarla bağdaştırıldığını göstermiştir. Yazarlar, ekoturizm odak alanlarındaki aktörler için kavramın pratik temeline yeniden bakılmasını ve terimin kullanımının dilsel yeterliliklerini dikkate almayı önermişlerdir. Makalede çevresel sürdürülebilirlik için bir metafor olarak ekoturizmin Kenya'daki destinasyonlar tarafından inşa edildiği farklı pozisyonları kategorize etmede kullanılmıştır. Yazarlar, bir metafor olarak ekoturizmin Kenya'daki korunan alanlardaki koruma girişimlerinin ikonik bir temsili olarak öne çıkmayı başardığı noktası üzerinde durmuşlardır.

Matlay ve Peters (2005) bir kuruluştaki genç stajyerler veya çıraklar gibi bazı paydaş gruplarının girişimci süreçler ve liderlik becerileri hakkında daha derin bir bilgiye sahip olabileceğini öne sürmektedir. Çalışmada küçük işletme girişimcilerinin turizmdeki temel özelliklerini araştırmakta ve insan kaynakları yönetimi ile ilgili becerileri rapor edilmektedir. Çalışmada 
girişimci liderin, çalışanların işe ilgilerini odaklayabilmeleri için çalışanlar üzerinde güçlü bir etkisinin olduğunu, sadece çalışanların değil stajyerlerin de motive edilmesi, şirketlerin iç iletişiminin ve uygun bir çalışma atmosferinin oluşturulmasından sorumlu olduğu üzerinde durmuştur. Çalışmada stajyerlerin liderlik davranışı değerlendirilmiş ve bunun için anket çalışması yapılmıştır. Anket kapsamında, çalışanların örneğin şirket içindeki üst birim yöneticisi genel müdür veya şirket sahibi yöneticinin çalışanları motivasyonu ve çalışanlarla iletişim yeteneğinin yanı sıra insan kaynakları yönetimi becerilerinin de değerlendirmesi sağlanmıştır. Stajyerlerin girişimci liderlik değerlendirmesini açıklamak ve tahmin etmek için hangi değişken kümesinin kullanılabileceğini araştırmak amacıyla tanımlayıcı analiz, k-ortalama küme analizi ve çoklu regresyonlar kullanılmıştır. Stajyerler tarafından "Çalışan dostu liderler" sık sık iletişim kuran ve onları iş başında eğitmeye çalışan yönetici olarak tanımlanmıştır. Bu tür yöneticilerin stajyerleri motive ettiği belirlenmiştir. Matlay ve Peters (2005)'e göre turizm çalışanları tarafından algılanan en büyük avantajlardan biri, dünyadaki turizm merkezlerinde kolayca iş bulma imkânı bulunmasıdır. Genç turizm stajyerleri için güçlü bir motivasyon kaynağı diğer ülkeleri ve kültürleri öğrenme imkânıdır ve bu nedenle de mesleki hareketliliklerinin desteklenmesi oldukça önemlidir. Öte yandan, girişimci liderlerin uzun vadede kalifiye çalışanları kaybetmekten korktukları çalışmanın bir sonucu olarak ortaya çıkmaktadır. Daha esnek ve kültürlerarası eğitim programları, hem mevcut eğitim firmalarıyla daha yüksek stajyer memnuniyetini hem de uluslararası know-how'ın küçük turizm işletmelerine daha iyi aktarılmasını sağlayabileceği not edilmiştir.

Richardson (2008) Avustralya'daki mevcut turizmi ve konaklama bölümünde lisans eğitimi alan öğrencilerinin sektördeki kariyerlerine yönelik tutum ve algılarını incelemiş öğrencilerin endişe duyduğu alanlar, yöneticileriyle olan ilişkisi, tanıtım fırsatları, kariyer yolları ve sektörde sunulan ücret ve koşullar çalışmada irdelemiştir. Çalışmada eğitim alan öğrencilerin \% 50'sinden fazlasının sektör dışındaki kariyerleri düşündüğü sonucuna varılmıştır. Sektörde iş tecrübesi olanların \% 43,6'sı mezun olduktan sonra turizm ve otelcilik sektöründe çalışmayacaklarını, bu katılımcıların \% 96,3'ünün bu kararın ana nedeninin de sektörde geçirdikleri tecrübeleri olduğu görülmüştür. Bu sonuç tek başına bile staj konusunun sadece sektörü tanıma ve öğrenme süreci olmadığını aynı zamanda kötü deneyimlerin alınan eğitimi etkisizleştirdiğini ortaya koymuştur. Stajyerlerin mezun olduktan sonra ilk olarak hangi pozisyonu düşündükleri belirlemek için bir dizi soru sorulmuş ve katılımclların çoğunluğunun süpervizör $(\% 16,5)$, stajyer müdürü $(\% 27,1)$, departman müdürü $(\% 15,3)$ ve müdür yardımcısı $(\% 17,6)$ gibi pozisyonlarda çalışabileceklerine inandıkları görülmüştür.

Akış Roney ve Öztin (2007) turizm eğitimi alan öğrencilerin turizm kariyerlerine yönelik algılarını analiz etmek için üniversite düzeyinde turizm eğitimi gören 450 Türk öğrenci ile anket çalışması yapmıştır. Sonuçlar, genel olarak, katılımcıların algılarının ne olumlu ne de olumsuz olduğunu göstermiştir. Bulgular ayrıca turizm sektörünü tanıma isteği; mezuniyet sonrası turizmde çalışmaya istekli olma ve iş tecrübesi; turizm kariyer imajını şekillendirmede önemli faktörler dikkate alınarak yürütülmüsstür. Çalışma, yeni öğrenciler sektöre iyimser bir bakışla başlasalar bile, staj döneminden ve (bazı öğrenciler için) yarı zamanlı iş deneyiminden sonra, daha olumsuz bir algı geliştiği görülmüştür. Bunun birçok turizm işletmesinde insan kaynakları politikalarında ve uygulamalarında karmaşıklık eksikliği ile açıklanabileceği üzerinde durulmuştur. Genel olarak, yöneticilerin karar verme sürecine katılma yetkisini teşvik etme ve iş gücünü motive etme konusunda isteksiz olmalarının olumlu bakışın olumsuza dönmesinde etkili olabileceği düşünülebilir. Olumsuz çalışma koşullarının katılımcıların algıları üzerindeki etkisi büyüktür. Öğrenciler gerçekten turizm eğitimi almak ve sektörde kariyer yapmakla ilgilendiklerinde, turizmle ilgili işlerin doğası hakkında daha gerçekçi bir görüşe sahip olma eğilimindedirler, bu da daha mantıklı beklentiler anlamına gelmektedir. Turizm endüstrinin 
olumsuz imajının nedenlerinden biri, insan kaynaklarında güncel olmayan yaklaşımların kullanılmasından kaynaklanmakta ve bu da stajyer öğrencilerin bakışını olumsuza çevirmektedir. Yüksek kaliteli profesyonel insan kaynakları, iş deneyiminin kalitesini artırmaya ve sonuç olarak endüstrinin imajını potansiyel olarak iyileştirmeye yardımcı olabilir.

\section{YÖNTEM}

\section{Araştırma Deseni}

Yapılan bu araştırmada nitel araştırma yöntemlerinden olgubilim kullanılmıştır. Olgubilim, olgu hakkında bilgi sahibi olabilmek için kişilerin tecrübelerinden faydalanan bir araştırma yöntemidir (Kocabıyık, 2016: 55).

\section{Çalışma Grubu}

Çalışma grubunun demografik özelliklerine ilişkin bulgular aşağıdaki Tablo 1'de verilmiştir. Analiz sonucuna göre katılımcıların \%64'ü erkek, \%36'sı ise kadındır. Yaş dağılımı incelendiğinde, katılımcıların \%33'ü 21-30 yaş aralığında, \%27'si 31-40 yaş aralığında, \%40'ı ise 41 ve yaş üzerindedir. Medeni durum incelendiğinde, katılımcıların \%60'1 evli, \%38'i bekar ve \%2'si boşanmıştır. Eğitim durumu incelendiğinde, katılımcıların \%2'si ilköğretim, \%18'i ortaöğretim, \%18'i önlisans, \%56's lisans ve \% 7'si lisansüstü seviyede eğitim almıştır. Son olarak çalışılan departman incelendiğinde, katılımclların \%2'si rezervasyon, \%4'ü önbüro, \%18'i kat hizmetleri, \%27'si F\&B - mutfak, \%44'ü insan kaynakları ve \%4'ü muhasebe departmanında çalışmaktadır.

Tablo 1. Katılımcların Demografik Özelliklerine İlişkin Bulgular

\begin{tabular}{|l|l|c|c|}
\hline Değişkenler & \multicolumn{1}{|c|}{ Grup } & f & \% \\
\hline \multirow{4}{*}{ Cinsiyet } & Kadın & 16 & 35,6 \\
\cline { 2 - 4 } & Erkek & 29 & 64,4 \\
\hline \multirow{4}{*}{ Yaş } & $21-30$ & 15 & 33,3 \\
\cline { 2 - 4 } & $31-40$ & 12 & 26,7 \\
\cline { 2 - 4 } & 41 ve üstü & 18 & 40,0 \\
\hline \multirow{4}{*}{ Eüitim } & Evli & 27 & 60,0 \\
\cline { 2 - 4 } & Bekar & 17 & 37,8 \\
\cline { 2 - 4 } & Boşanmış & 1 & 2,2 \\
\cline { 2 - 4 } & Ilköğretim & 1 & 2,2 \\
\cline { 2 - 4 } & Lise & 8 & 17,8 \\
\cline { 2 - 4 } & Ön Lisans & 8 & 17,8 \\
\cline { 2 - 4 } & Lisans & 25 & 55,6 \\
\cline { 2 - 4 } & Lisans Üstü & 3 & 6,7 \\
\hline \multirow{5}{*}{ Departman } & Rezervasyon & 1 & 2,2 \\
\cline { 2 - 4 } & Önbüro & 2 & 4,4 \\
\cline { 2 - 4 } & Kat Hizmet & 8 & 17,8 \\
\cline { 2 - 4 } & F\&B - Mutfak & 20 & 44,7 \\
\cline { 2 - 4 } & İnsan Kay. & 2 & 4,4 \\
\cline { 2 - 4 } & Muhasebe & & 26 \\
\hline
\end{tabular}




\section{Veri Toplama Aracı}

Araştırma kapsamında veri toplama aracı olarak anket formu kullanılmıştır. Kullanılan anket formu iki bölümden oluşmaktadır. Anketin birinci kısmında katılımcıların demografik bilgilerini belirlemek amacıyla hazırlanmış 5 soru bulunmaktadır. Anketin ikinci kısmında ise katılımcıların stajyer metaforik algılarını belirlemek amacıyla boşlukları doldurmaları için verilmiş "Bence Stajyer ........ benzer, çünkü ........" şeklinde iki adet cümle bulunmaktadır. Formun nasıl doldurulacağı katılımcılara açıklanmıştır.

\section{Verilerin Analizi}

Verilerin analizinde Saban (2008)'in belirttiği kodlama ve ayıklama, örnek metafor imgesi derleme, kategori geliştirme, geçerlik ve güvenirliği sağlama ve yorumlama aşamaları uygulanmıştır. Bu bağlamda ilk olarak kodlama ve ayıklama aşamasında her bir form tek tek incelenmiş, tam anlaşılamayan, mantıksal gerekçeye dayandırılamayan, eksik, hatalı ya da boş olan toplam 18 adet form elenmiş, geçerli olarak 45 adet form elde edilmiştir. Geçerli sayılan 45 formdan elde edilen metaforlar alfabetik sıra ile Microsoft excel dosyasında listelenmiştir. Örnek metafor imgesi derleme aşamasında, metaforların belirli bir kategori altında yer alması için gereksiz uzun olan cümlelerin önemli kısımları alınarak örnek metafor listesi yapılmıştır. Ayrıca her bir metaforun hangi katılımcıya ait olduğunu belirlemek adına (Katılımc11, Katılımc12) şeklinde kodlamalardan faydalanılmıştır. Kategori geliştirme aşamasında, katılımcılar tarafından belirlenen metaforların ortak özelliklerine bakılmıs, birbirleri ile ilgili olanlar aynı kategori altına alınmıştır. Bu işlem sonunda metaforlar 4 kategori altında toplanmıştır. Geçerlik ve güvenirliği aşamasında, toplam 4 kategoride toplanan 32 metafor ile ilgili 2 uzmanın görüşüne başvurulmuştur. Uzmanların aynı ve farklı bulduğu kategoriler karşılaştırılmıştır. Bu karşılaştırma sonucunda "görüş birliği" ve "görüş ayrıllı̆ı" sayıları tespit edilmiştir. Bu sayıların tespit edilmesinin ardından Miles ve Huberman'ın (1994: 64) çalışmasında belirttiği formül (Güvenirlik = görüş birliği / görüş birliği + görüş ayrıllı̆ı $\times 100$ ) kullanılarak araştırmanın güvenirliği belirlenmiştir. Elde edilen sonuç, uzmanların \%94 oranında görüş birliğinde olduğunu göstermiştir. Uzmanlar 30 metafor ile ilgili görüş birliğine varmıştır. Görüş birliğine varılamayan 2 adet metafor ise araştırma kapsamından çıkarılmıştır. Son olarak yorumlama aşamasında, metaforlar ayrıntılı şekilde bulgular başlı̆̆ı altında açıklanmaya çalışılmıştır.

\section{BULGULAR}

Araştırma kapsamında otel işletmelerinde çalışan toplam 63 kişiye anket uygulanmıştır. Uygulanan anketlerden 18 tanesi geçersiz sayılırken, 45 tanesi geçerli sayılmıştır. Geçerli olan 45 anket formundan 30 adet metafor elde edilmiştir. Elde edilen 30 metafor 4 kategori (ilgilenildikçe gelişen birey, yokluğu eksiklik, varlığı yenilik yaratan birey, tecrübeyle gelişecek birey, geleceğe yön verecek birey) altında toplanmıştır. Katılımcılardan elde edilen metaforlara ilişkin kategoriler ve kod frekanslarına aşağıdaki Tablo 2'de verilmiştir.

Stajyer kavramına ilişkin otel yöneticilerinin belirttikleri metaforlar ortak özellikleri bakımından dört kategori (ilgilenildikçe gelişen birey, yokluğu eksiklik, varlığı yenilik yaratan birey, tecrübeyle gelişecek birey, geleceğe yön verecek birey) altında toplanmıştır. Kategorilere ilişkin detaylı bilgilere aşağıda yer verilmiştir. 
Tablo 2. Stajyer Kavramına İlişkin Kategori ve Kod Frekansları Tablosu

\begin{tabular}{|c|c|c|}
\hline Kategori & Kod & $\mathrm{f}$ \\
\hline \multirow{15}{*}{ İlgilenildikçe gelişen birey } & Fidan & 6 \\
\hline & Çiçek & 5 \\
\hline & Yaş bir ağaç & 3 \\
\hline & İşlenmemiş maden & 2 \\
\hline & İşlenmemiş demir & 1 \\
\hline & İşlemeye hazır altın & 1 \\
\hline & Dikilmemiş kumaş & 1 \\
\hline & Yemek & 1 \\
\hline & Hamur & 1 \\
\hline & Tohum & 1 \\
\hline & Dokunacak bir halı & 1 \\
\hline & Arazi & 1 \\
\hline & Okula yeni başlayan öğrenci & 1 \\
\hline & Meslekle ilgili tüm verileri depolayan yapı & 1 \\
\hline & Kaynak & 1 \\
\hline \multirow{4}{*}{$\begin{array}{l}\text { Yokluğu eksiklik, varlığı } \\
\text { yenilik yaratan birey }\end{array}$} & İyi bir başlangıç & 1 \\
\hline & Papatya dalı & 1 \\
\hline & Bina temeli & 1 \\
\hline & Taze kan & 1 \\
\hline \multirow{5}{*}{ Tecrübeyle gelişecek birey } & Gençlik & 2 \\
\hline & Yeni emeklemeye başlayan bebek & 2 \\
\hline & Roman yazmaya yeni başlayan bir yazar & 1 \\
\hline & Yeni doğmuş civciv & 1 \\
\hline & Sayfaları yazılmamış boş bir kitap & 1 \\
\hline \multirow{6}{*}{$\begin{array}{c}\text { Geleceğe yön verecek } \\
\text { birey }\end{array}$} & Gelecek turizm yüzümüz & 2 \\
\hline & Diksiyonu düzgün birey & 1 \\
\hline & Bilinçli birey & 1 \\
\hline & Gelecek vaad eden yönetici & 1 \\
\hline & Geleceğimiz & 1 \\
\hline & İşe ve geleceğe yönelik potansiyel & 1 \\
\hline
\end{tabular}

\section{İlgilenildikçe Gelişen Birey Kategorisi}

Stajyer kavramının ilgilenildikçe gelişen birey kategorisinde 27 kişinin (\%60) ürettiği 15 metafor bulunmaktadır. Bu kategoride genel olarak yöneticiler bireylere ne kadar özen gösterilir, onlarla ne kadar ilgilinilirse onların da o kadar gelişim göstereceğini ifade etmişlerdir.

Tablo 3. İlgilenildikçe Gelişen Birey Kavramına İlişkin Metaforlar

\begin{tabular}{|c|l|c|c|l|c|}
\hline Sıra & Metafor & f & Sıra & Metafor & f \\
\hline 1 & Fidan & 6 & 9 & Hamur & 1 \\
\hline 2 & Çiçek & 5 & 10 & Tohum & 1 \\
\hline 3 & Yaş bir ağaç & 3 & 11 & Dokunacak bir halı & 1 \\
\hline 4 & İşlenmemiş maden & 2 & 12 & Arazi & 1 \\
\hline 5 & İşlenmemiş demir & 1 & 13 & Okula yeni başlayan öğrenci & 1 \\
\hline 6 & İşlemeye hazır altın & 1 & 14 & Meslekle ilgili tüm verileri depolayan yapı & 1 \\
\hline 7 & Dikilmemiş kumaş & 1 & 15 & Kaynak & 1 \\
\hline 8 & Yemek & 1 & \multicolumn{3}{|c}{} \\
\hline
\end{tabular}


Katılımcı1 "Stajyer işlenmemiş demire benzer, çünkü sıfırdan başlar işleyip şekle sokmak dikkat ister."

Katılımc19 “Stajyer hamura benzer, çünkü istediğiniz şekilde yoğurabilirsiniz."

Katılımcı10 “Stajyer dokunacak bir halıya benzer, çünkü nasıl işleyip dokursan yön verirsen öyle olur."

Katılımc113 "Stajyer meslekle ilgili tüm verileri depolayan yapıya benzer, çünkü doğruyu verirsek verim alabiliriz."

Katılımcı15 "Stajyer yaş bir ağaca benzer, nasıl eğitirsek ne öğretirsek o doğrultuda şekillenir."

Katılımc117 "Stajyer çiçeğe benzer, çünkü gerekli ilgi ve bilgi verildikten sonra değişip güzelleşir."

Katılımc122 “Stajyer araziye benzer, çünkü emek verilirse yeşerir.

Katılımcı23 “Stajyer okula yeni başlayan öğrenciye benzer, çünkü başlangıçta nasıl yoğurursan o düzende gider."

Katılımc128 "Stajyer işe ve geleceğe yönelik potansiyele benzer, çünkü elmas gibi işlenmesi gerekir."

Katılımc133 "Stajyer işlenmemiş madene benzer, çünkü maden gibi işlem gördükçe parlar ve değeri artar."

Katılımcı34 "Stajyer fidana benzer, çünkü iş hayatında öğrendikçe gelişecek dallanıp budaklanacak ve yeşerecek."

Katılımcı35 "Stajyer işlemeye hazır altına benzer, çünkü içlerindeki o heyecan işlerine yansır ve en iyisini yapmak ister."

Katılımc140 "Stajyer kaynağa benzer, çünkü yaptığımız işi ne kadar bilinçli yaparsak o kadar verim alırız."

\section{Yokluğu Eksiklik, Varlığı Yenilik Yaratan Birey Kategorisi}

Stajyer kavramının yokluğu eksiklik, varlığı yenilik yaratan birey kategorisinde 4 kişinin $(\% 8,88)$ ürettiği 4 metafor bulunmaktadır. Bu kategoride genel olarak bireylerin varlığının kuruma güç ve yenilik katacağı, yokluğunun ise kurumu eksik ve temelsiz bırakacağı ifade edilmiştir.

Tablo 4. Yokluğu Eksiklik, Varlığı Yenilik Yaratan Birey Kavramına İlişkin Metaforlar

\begin{tabular}{|c|l|c|}
\hline Sıra & Metafor & f \\
\hline 1 & İyi bir başlangıç & 1 \\
\hline 2 & Papatya dalı & 1 \\
\hline 3 & Bina temeli & 1 \\
\hline 4 & Taze kan & 1 \\
\hline
\end{tabular}

Katılımcı3 “Stajyer taze kana benzer, çünkü güç verir, yenilik katar."

Katılımcı14 "Stajyer iyi bir başlangıca benzer, çünkü geleceğin temelidir."

Katılımcı25 "Stajyer binanın temeline benzer, çünkü temel ne kadar iyi ve kaliteli olursa bina o kadar sağlam olur." 
Katılımcı26 "Stajyer papatyanın dalına benzer, çünkü otelde stajyer olmadığı sürece eksik kalır."

\section{Tecrübeyle Gelişecek Birey Kategorisi}

Stajyer kavramının tecrübeyle gelişecek birey kategorisinde 7 kişinin $(\% 15,55)$ ürettiği 5 metafor bulunmaktadır. Bu kategoride genel olarak yöneticiler bireylerin zaman içerisinde tecrübe kazandıkça gelişeceğini ifade etmişlerdir.

Tablo 5. Tecrübeyle Gelişecek Birey Kavramına İlişkin Metaforlar

\begin{tabular}{|c|l|c|}
\hline \multicolumn{1}{|l|}{ Sıra } & Metafor & f \\
\hline 1 & Gençlik & 2 \\
\hline 2 & Yeni emeklemeye başlayan bebek & 2 \\
\hline 3 & Roman yazmaya yeni başlayan bir yazar & 1 \\
\hline 4 & Yeni doğmuş civciv & 1 \\
\hline 5 & Sayfaları yazılmamış boş bir kitap & 1 \\
\hline
\end{tabular}

Katılımcı8 "Stajyer sayfaları yazılmamış boş bir kitaba benzer, çünkü bilgi ve tecrübeleriyle kendi kitabını yazar."

Katılımc120 "Stajyer roman yazmaya yeni başlayan bir yazara benzer, çünkü zaman geçtikçe yenilenir, yazdıkça güzelleşir."

Katılımcı32 "Stajyer yeni emeklemeye başlayan bebeğe benzer, çünkü sürekli deneyim kazanarak yol kateder."

Katılımc139 "Stajyer yeni doğmuş civcive benzer, çünkü hayatı yavaş yavaş ve bir o kadar da yırtıcı olarak öğrenir. Kendini geliştirdiği takdirde başarılı olabilir".

Katılımcı45 "Stajyer gençliğe benzer, çünkü geleceğimiz olan bireyleri en iyi şekilde eğitip topluma kazandırmalıyız."

\section{Geleceğe Yön Verecek Birey Kategorisi}

Stajyer kavramının geleceğe yön verecek birey kategorisinde 7 kişinin $(\% 15,55)$ ürettiği 6 metafor bulunmaktadır. Bu kategoride genel olarak yöneticiler bireylerin geleceğe yön verecek potansiyelleri olduğunu ifade etmişlerdir.

Tablo 6. Geleceğe Yön Verecek Birey Kavramına İlişkin Metaforlar

\begin{tabular}{|c|l|c|}
\hline Sıra & Metafor & f \\
\hline $\mathbf{1}$ & Diksiyonu düzgün birey & 1 \\
\hline $\mathbf{2}$ & Bilinçli birey & 1 \\
\hline $\mathbf{3}$ & Gelecek vaad eden yönetici & 1 \\
\hline $\mathbf{4}$ & Geleceğimiz & 1 \\
\hline $\mathbf{5}$ & Gelecek turizm yüzümüz & 2 \\
\hline $\mathbf{6}$ & İşe ve geleceğe yönelik potansiyel & 1 \\
\hline
\end{tabular}

Katılımc15 “Stajyer gelecek turizm yüzümüze benzer, çünkü yeni taze yetişen birer turizimci olacaklar ve yeni turizmciler yetiştirecekler."

Katılımcı30 "Stajyer bilinçli bireylere benzer çünkü, uygulamayı hayaline sığdıranbilen öğrencilerdir." 
Katılımcı38 "Stajyer diksiyonu düzgün bireye benzer, çünkü turizmin olmazsa olmazıdır."

Katılımcı44 "Stajyer gelecek vaad eden yöneticiye benzer, çünkü ne istediğini ve ne yapması gerektiğini bilir."

Toparlamak gerekirse ortaya çıkan dört kategorideki tüm metaforlar yöneticilerin stajerlerle ilgili düşüncelerinin olumlu olduğunu göstermektedir. En fazla (15) metaforun üretildiği ilgilenildikçe gelişen birey kategorisi stajyerlerin gelişiminde çalıştıkları kurumlarda karşılarına çıacak yöneticilerin onların gelişiminde büyük rolu olduğunu göstermektedir. Diğer kategorilerde oluşan metaforlar da varlıklarının kurumlar için çok gerekli olduğunu, zaman içerisinde deneyim kazandıkça mesleklerinde ilerleme kaydedeceklerini ve günün sonunda turizmin geleceğine yön verecek kişilerin onların olduğuna dikkat çekmektedir.

\section{SONUÇ}

Yapılan bu araştırmada, otel işletmelerinde çalışan yöneticilerin "stajyer" kavramına ilişkin sahip oldukları metaforları belirlemek amaçlanmıştır. Bu amaç doğrultusunda toplam 45 yöneticiye anket uygulanmıştır. Geçerli olan 45 anket formundan 30 adet metafor elde edilmiştir. Elde edilen 30 metafor 4 kategori (ilgilenildikçe gelişen birey, yokluğu eksiklik, varlığı yenilik yaratan birey, tecrübeyle gelişecek birey, geleceğe yön verecek birey) altında toplanmıştır. İlgilenildikçe gelişen bir birey kategorisinde 27 kişinin (\%60) ürettiği 15 metafor bulunmaktadır. Bu kategoride genel olarak yöneticiler bireylere ne kadar özen gösterilir, onlarla ne kadar ilgilinilirse onların da o kadar gelişim göstereceğini ifade etmişlerdir. Bu kategoride yöneticiler stajyerleri en çok sırasıyla fidan ( $f=6$ ) ve çiçeğe $(f=5)$ benzetmiştir. Fidan ve çiçeği sırasıyla yaş bir ağaç ( $f=3$ ) ve işlenmemiş maden $(\mathrm{f}=2)$ takip etmiştir. Diğer metaforlar ise sırasıyla; işlenmemiş demir, işlemeye hazır altın, dikilmemiş kumaş, yemek, hamur, tohum, dokunacak halı, arazi, okula yeni başlayan öğrenci, meslekle ilgili veri depolayan bir yapı ve kaynaktır. Stajyer kavramının yokluğu eksiklik, varlığı yenilik yaratan birey kategorisinde 4 kişinin $(\% 8,88)$ ürettiği 4 metafor bulunmaktadır. Bu kategoride genel olarak bireylerin varlığının kuruma güç ve yenilik katacağı, yokluğunun ise kurumu eksik ve temelsiz bırakacağı ifade edilmiştir. Bu kategoride yöneticiler stajyerleri iyi bir başlangıç, papatya dalı, bina temeli ve taze kana benzetmiştir. Stajyer kavramının tecrübeyle gelişecek birey kategorisinde 7 kişinin $(\% 15,55)$ ürettiği 5 metafor bulunmaktadır. Bu kategoride genel olarak yöneticiler bireylerin zaman içerisinde tecrübe kazandıkça gelişeceğini ifade etmişlerdir. Bu kategoride yöneticiler stajyerleri en çok gençliğe $(\mathrm{f}=2)$ ve yeni emeklemeye başlayan bebeğe $(\mathrm{f}=2)$ benzetmiştir. Diğer metaforlar ise roman yazmaya yeni başlayan bir yazar, yeni doğmuş civciv ve sayfaları yazılmamış boş bir kitaptır. Son olarak stajyer kavramının geleceğe yön verecek birey kategorisinde 6 kişinin $(\% 13,33)$ ürettiği 5 metafor bulunmaktadır. Bu kategoride genel olarak yöneticiler bireylerin geleceğe yön verecek potansiyelleri olduğunu ifade etmişlerdir. $\mathrm{Bu}$ kategoride yöneticiler stajyerleri en çok gelecek turizm yüzümüze $(\mathrm{f}=2)$ benzetmiştir. Diğer metaforlar ise diksiyonu düzgün birey, bilinçli birey, gelecek vaad eden yönetici ve geleceğimize benzetmişlerdir.

Elde edilen sonuçlar bu alanda çalışan yöneticilerin stajyerlere yönelik algısının genel olarak pozitif olduğu yönündedir. Stajyer öğrencilere dönük yapılan diğer çalışmalarla birlikte değerlendirildiğinde bazı yararlı öneriler sunulabilir. Literatürdeki mevcut çalışmalar stajyerlerin iş algısındaki negatif durumların varlığına işaret etmektedir, staj döneminin ucuz işgücü kaynağı olarak değerlendirilmemesi ve yöneticilerin sahip oldukları pozitif algının öğrencilerin ihtiyacı olan bilgi ve tecrübe aktarımı ile değerlendirilmesi öğrencilerin sektörde kalma istekleri üzerine olumlu etkide bulunacaktır. 


\section{KAYNAKÇA}

Adu-Ampong, E. (2016). A metaphor analysis research agenda for tourism studies. Annals of Tourism Research, 57, 248-250.

Akış Roney, S., and Öztin, P. (2007). Career perceptions of undergraduate tourism students: A case study in Turkey. Journal of Hospitality, Leisure, Sport and Tourism Education, 6(1): 4-17.

Atieno, L., and Njoroge, J. M. (2018). The ecotourism metaphor and environmental sustainability in Kenya. Tourism and Hospitality Research, 18(1): 49-60.

Bilgen, N., Şahin, M. H, and Karatepe, A. (2014). Analysis of vocational high school and vocational secondary school students' thoughts towards thermal tourism concept using metaphors. SDU International Journal of Educational Studies, 1(2): 80-87.

Burke, K. (1966). Language as Symbolic Action. Essays on Life, Literature and Method. University of California Press, Berkeley.

Cameron, L., and Maslen, R. (eds.) (2010) Metaphor analysis: research practice in applied linguistics, social sciences and humanities. London: Equinox Publishing.

Canbaba, İ., ve Canbaba, Z. (2020). Turizm Meslek Yüksekokulu Öğrencilerinin “Termal Turizm”'kavramına İlişkin Algılarının Metafor Yöntemiyle İncelenmesi. 1. Uluslararası Kış Turizmi Kongresi Bildiriler Kitabı.

Carver, T., and Pikalo, J. (eds) (2008). Political language and metaphor: interpreting and changing the world. London: Routledge.

Chen, T.B., and Gürsoy, D. (2008). Preparing students for careers in the leisure, recreation and tourism field. Journal of Teaching in Travel and Tourism, 7(3): 21-41.

Cook, S., Parker, R., and Pettijohn, C. (2004). The perception of interns: A longitudinal case study. Journal of Education for Business, 79(3): 179-186.

Dann, G. M. S. (2002). The tourist as a metaphor of the social world. In: Dann, G. M. S (ed.) The tourist as a metaphor of the social world. Oxford: Cabi Publishing.

Dilek, N. K., Dilek, S. E., ve Gümüş, M. (2016). Otel çalışanlarının turizm ve barış ilişkisine yönelik metaforik algıları. Batman Üniversitesi Yaşam Bilimleri Dergisi, 6(2/1): 1-15.

Ehtiyar, V. R., Solmaz, C., ve Çağla, Ü. S. T. (2019). "Kadın Akademisyen” Olmak: Turizm Alanındaki Kadın Akademisyenlere Yönelik Bir Metafor Çalışması. Seyahat ve Otel İşletmeciliğ $i$ Dergisi, 16(2): 296-318.

Elgin, S. (1993). Genderspeak. Men, Women and the Gentle Art of Verbal Self-defense. John Wiley \& Sons, New York.

Emir, O., Pelit, E., ve Arslan, S. (2010). Turizm Alanında Önlisans Eğitimi Alan Öğrencilerin Staj Öncesi ve Sonrası Görüşlerinin Karşılaştırılması (Afyon Kocatepe Üniversitesi Örneği). Elektronik Sosyal Bilimler Dergisi, 9(33): 141-165.

Gözen, E. (2019). Rekreasyon Yönetimi Bölümü Lisans Öğrencilerinin Rekreasyon Kavramına İlişkin Metaforik Algıları. Stratejik ve Sosyal Araştırmalar Dergisi, 3(3): 397-416.

Güllü, M., Kendir, H. ve Ince, C. (2016). Turizm Eğitimi Alan Lisans Öğrencilerinin İş Değeri Algıları ve Mesleğe Devam Niyetleri: Stajyer Öğrencilere Yönelik Bir Araştırma/Tourism 
Students'perceptions of Job Values and Occupational Commitment: A Research on Trainee Students. Turan: Stratejik Araştırmalar Merkezi, 8(32): 567.

Günay, E., and Düşmezkalender, E. (2019). Analysis of the Concepts of Tourism and Tourist by Metaphors. City Tourism, 399.

Gürsoy, İ. T., ve Sonuç, N. (2020). Turizm ve Kültür: Lise ve Üniversite Öğrencilerinin Algılarına İlişkin Metafor Analizi. OPUS Uluslararası Toplum Araştırmaları Dergisi, 15(23): 1809-1828.

Kocabıyık, O. O. (2016). Olgubilim ve gömülü kuram: bazı özellikler açısından karşılaştırma. Trakya Üniversitesi Ĕ̆itim Fakültesi Dergisi, 6(1): 55-66.

Köroğlu, Ö., Manav, S., ve Karaca, K. Ç. (2018). Turizm Rehberliği Öğrencilerinin" Türk Mutfağı" Kavramına İlişkin Algılarının Metaforlar Yöntemi ile Belirlenmesi. Sosyal ve Beşeri Bilimler Dergisi, 10(2): 114-129.

Lakoff, G., and Johnson, M. (1980). Metaphors we live by. Chicago: University of Chicago Press.

Matlay, H., and Peters, M. (2005). Entrepreneurial skills in leadership and human resource management evaluated by apprentices in small tourism businesses. Education + Training, 47(8/9): 575-591.

Miles, M. B., and Huberman, A. M. (1994). Qualitative data analysis. Thousand Oaks. CA: Sage.

Nöth,W. (1990). Handbook of Semiotics. Indiana University Press, Bloomington.

Özder, A., Kaya, H., ve Ünlü, M. (2012). Ortaöğretim Öğrencilerinin “Turizm” Kavramı ile İlgili Geliştirdikleri Metaforların Analiz Örneği. Marmara Coğrafya Dergisi, (25): 18-31.

Parın, K. (2017). Metaforlar: Hayat, Anlam ve Dil. Söylem Filoloji Dergisi, 2(1): 149-151.

Pender, L., and Sharpley, R. (Eds.). (2004). The management of tourism. Sage. London.

Richardson, S. (2008). Undergraduate Tourism and Hospitality Students Attitudes Toward a Career in the Industry: A Preliminary Investigation, Journal of Teaching in Travel \& Tourism, 8(1): 23-46, DOI: $10.1080 / 15313220802410112$

Saban, A. (2008). Okula İlişkin Metaforlar. Kuram ve uygulamada eğitim yönetimi, 55(55): 459-496.

Saçlık, M., Çevik, S., ve Özkan, Ç. (2016). Turizm ve Otel İşletmeciliği Bölümü Önlisans Öğrencilerinin" Turizm" Olgusuna İlişkin Metaforik Algıları. Akademik Bakış Dergisi, 53: 84-103.

Seyitoğlu, F., and Çakar, K. (2017). Tourism education and internships: a metaphor analysis. Journal of Teaching in Travel \& Tourism, 17(4): 269-280.

Taş, M., Düz, İ., ve Ünlü, E. (2016). Ortaöğretim öğrencilerinin "alternatif turizm" kavramına ilişkin algılarının metaforlar yardımıyla analizi. Eğitim ve Öğretim Araştırmaları Dergisi, 5(39): 352360 .

Zopiatis, A., and Constanti, P. (2007). Human resource challenges confronting the Cyprus hospitality industry. EuroMed Journal of Business, 2(2): 135-153. 